\title{
Women and Terrorism: A Sketch on Women and Transnational Terrorism in Southeast Asia and Indonesia
}

\author{
Herdi Sahrasad $^{1}$, Dedy Tabrani' ${ }^{2}$, Muhammad Ridwan ${ }^{3}$, Al Chaidar ${ }^{4}$ \\ ${ }^{1}$ University of Paramadina, Indonesia \\ ${ }^{2}$ Police Science College-PTIK Jakarta, Indonesia \\ ${ }^{3}$ State Islamic University of Sumatera Utara Medan, Indonesia \\ ${ }^{4}$ University of Malikussaleh, Aceh, Indonesia \\ bukharyahmedal@gmail.com
}

\begin{abstract}
In Southeast Asia, many women in radical groups have extreme views and they are ready to join Jihadist movement to support her husband's actions as Jihad fi sabilillah. In this context, experience in Southeast Asia shows the increasing involvement of women in terrorism by reason of following the husband's jihad to fight thogut regimes in the region. Meanwhile, there are a large number of Islamic terrorist organizations involving active women throughout the Southeast Asian region, from Thailand, Malaysia, Indonesia, Singapore to the Philippines. In this regard, the emergence of ISIS has strengthened and institutionalized acts of terror and violence by Southeast Asian women following the ISIS declaration to establish a regional khilafah (Caliphate).
\end{abstract}

Keywords

Women; terrorism Islam ISSS; Indonesia; Southeast Asia

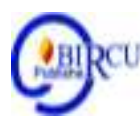

\section{Introduction}

In the 2000s Umm Osama (bin Laden), a senior woman in Al Qaeda, called for jihad to women around the world: transnational terrorism in action. The call was welcomed by actions in Russia, Checnya, and Palestine by women. Between 2000 and 2007, analysts (Speckhard and Akhmedova) noted that 46 of 110 suicide bombers were women. It is not impossible ten years after the cases that Umm Osama's call, this radical outcry for violence have reached Southeast Asian women.

The role of women in terrorism can no longer be taken lightly. Many women in radical groups have extreme views. In this research findings, for example, a wife of a terrorist prisoner views her husband's actions as jihad. She is as a wife who is patient waiting for her husband in prison will get the reward of jihad. In a conversation with us, she said that she would support her husband to return to jihad after his detention. Even if her husband is arrested again, it's no problem for her.

With such a view, it only takes one more stage for her to become a suicide bomber. Besides this woman, there are many women who are willing and proud to marry convicted terrorists. Our results show that at least six women are married to terrorism inmates in a prison in Nusakambangan, Indonesia. In other prisons in Malaysia and Phillipines, many of the same things happen. They do not care about the stigma of the terrorist wife and other difficulties as convict wives because of their pride in the mujahideen.

The emergence of ISIS has strengthened and institutionalized acts of terror and violence by women following the ISIS declaration to establish a regional khilafah (Caliphate). 
Konfrontasi Journal: Culture, Economy and Social Changes, 7 (1) March 2020, 56-66

ISSN: 1410-881X (Print), 2716-2095 (Online)

Herdi Sahrasad, Dedy Tabrani, Muhammad Ridwan, Al Chaidar: Women and Terrorism: A Sketch on

Women and Transnational Terrorism in Southeast Asia and Indonesia

DOI: https://doi.org/10.33258/konfrontasi2.v7i1.97

http://www.konfrontasi.net/index.php/konfrontasi2

In Southeast Asia, for instance, in the past (2017) the socio-political situation in Marawi city, the southern part of the Philippines has been dominated by the Southeast Asian's ISIS and this dangerous situation is a big concern for state and society in Southeast Asia. Although in the end Marawi could be controlled again by the Manila government, the bitter experience shows that terrorism is a serious problem in Asia

\section{Discussion}

In the Southeast Asian context, reports have shown that women from Indonesia, the Philippines, Singapore and Malaysia have been involved in ISIS at various levels. Of the four countries, reports indicate that women in Indonesia have participated in ISIS as suicide bombers recruiters and funders ${ }^{1}$.

It can be observed that, of all countries in Southeast Asia, four countries reported having women involved in ISIS, namely Indonesia, Malaysia, the Philippines, and Singapore. Of all, women in Indonesia appear to be the most active and radical, followed by the Philippines, Malaysia, and finally Singapore. The first female suicide bomber was Indonesian. However, not one but two of the two and both attempts failed. Recent events indicate that three families including women and children have succeeded in carrying out suicide bombings in three different places in Indonesia. As for Malaysians, from newspaper reports, it was revealed that the majority of them were motivated to migrate to the Caliphate to marry jihadists.

It can also be observed elsewhere that some women have other motivations for joining ISIS, for example, as a form of emancipation. This can be seen through social media where women take the lead - they recruit, distribute and raise funds, without permission or orders from men. They decide and determine their direction and embrace other women under the 'spirit of brotherhood'. All this has given women a sense of authority and independence, at the same time, a sense of worthiness and ownership. (see table 1)

Table 1. Foreign fighters in Syria and Iraq

\begin{tabular}{|l|l|l|l|}
\hline Countries & Official Count & Non-Official & Returnees \\
\hline Cambodia & 1 & & \\
\hline Indonesia & 700 & 500 & 162 \\
\hline Malaysia & 100 & & $5+$ \\
\hline Philippines & 100 & & \\
\hline Singapore & 2 & & \\
\hline
\end{tabular}

Source: The Soufan Group (2015, pp. 7-10).

In May 2018, Indonesia was rocked by a series of deadly terrorist attacks. According to police reports, the local extremist network affiliated with ISIS Jama'ah Ansharud Daulah (JAD), is responsible.

Various reports indicate that women from Indonesia, Malaysia, Singapore and the Philippines are directly involved in ISIS or terrorist groups affiliated with ISIS, both in their own countries, in neighboring Southeast Asian countries or in the Middle East. The women in the Southeast Asian region have played a variety of roles from traditional to radical. This

\footnotetext{
${ }^{1}$ Institute for Conflict Policy Analysis [IPAC], Report 2017Mothers to Bombers: The Evolution of Indonesian Women Extremists. IPAC Report No. 35.
} 
paper aims to look at the identities and causes of why women in Southeast Asia are involved in pro-ISIS terrorism and what role they play and their impact in the countries of the region.

Institute for Strategic Dialogue CEO Sarah Havlicek (2015) once stated that: The reality seems to be contradictory in the role of their online activists, the sub-culture of women who are jihadist and its aggressive level can be traced to incitement to hatred and violence. To consider them "naive" or "unaware" of ISIS's brutality is wrong and wrong. Havlicek suggested the use of soft power to fight terrorism, especially those related to radicalization. He pointed out that using drones and border actions cannot simply challenge radicalization. The target group must be those who support and sympathize with growing ISIS, not only individuals but also organizations such as Al Qaeda. When delivering this to the Foreign Affairs Committee, United States (US), he said "we must work at prevention, deradicalization, prevention, deradicalization, and at the strategic level to counter the underlying ideology".

Havlicek explained that the Institute for Strategic Dialogue has built and runs the largest global network of ex-extremists globally, Against Violent Extremism (AVE), in collaboration with the Google Ideas and GenNext Foundation. The voice of a former extremist is crucial for reaching recruits, in a far more convincing way. However, he also points out that there are large gaps in counter-narratives and outreach targeting girls and "at risk" women. They need to develop messages that specifically target female audiences Women practitioners in counterterrorism, counter-extremism and deradicalization will be very important. This is not a matter of equality, but female practitioners will be more capable than men, to engage with young women because "fundamentalist gender roles strengthen in the process of radicalization" (Havlicek, 2015, p. 17) 2 .

In the Southeast Asian context, reports have shown that women from Indonesia, the Philippines, Singapore and Malaysia have been involved in ISIS at various levels. Of the four countries, reports indicate that women in Indonesia have participated in ISIS as suicide bombers. There are a large number of Islamic terrorist organizations involving active women throughout the Southeast Asian region, from Thailand, Malaysia, Indonesia, Singapore to the Philippines. Not all radical organizations are part of ISIS which is very radical and cruel. Jemaah Islamiyah (JI) for example, which in 2002 carried out a bombing in Bali and killed more than 200 people, they were not part of ISIS. Nevertheless, Southeast Asia is the goal of ISIS. Zachary Abuza, Southeast Asia expert from National War College, Washington D.C. and Colin P. Clarke of RAND Corporation, in a joint report on a security blog, Fortuna's Corner, concluded that "Southeast Asia is likely to be the best place for Islamic militants."

After losing territory in Syria and Iraq in March 2019, ISIS has transformed itself into a decentralized global terrorist organization. According to experts, the Southeast Asian region was targeted by ISIS because it is difficult to control with the many islands that are very suitable for ISIS infiltration.

It can be observed that, of all countries in Southeast Asia, four countries reported having women involved in ISIS, namely Indonesia, Malaysia, the Philippines, and Singapore. Of all, women in Indonesia appear to be the most active and radical, followed by the Philippines, Malaysia, and finally Singapore. The first female suicide bomber was Indonesian. However, not one but two of the two and both attempts failed. Recent events indicate that three families including women and children have succeeded in carrying out suicide bombings in three different places in Indonesia. As for Malaysians, from newspaper

\footnotetext{
${ }^{2}$ Sarah Havlicek, The Islamic State's War on Women and Girls. Institute for Strategic Dialogue. Institute for Policy Analysis of Conflict (IPAC), IPAC Report No. 33, 1-18, 2015
} 
reports, it was revealed that the majority of them were motivated to migrate to the Caliphate to marry jihadists.

There are very few active recruiters. However, recent developments indicate that there was a woman who tried to attack the polls in the 14th general election recently. Another Malaysian woman, Dr Sham, has stood out at the international level getting international media attention and has become the pride of ISIS. He still serves as a medical doctor in Syria to this day. All these women have different backgrounds including age, educational background, social status and economy. Many Malaysian women involved in ISIS are not linked to militant families. The reasons for their radicalization are different and are sometimes reported in newspapers that many of them want to seek blessings from Allah SWT by marrying jihadists or to cleanse themselves of their previous sins.

It can also be observed elsewhere that some women have other motivations for joining ISIS, for example, as a form of emancipation. This can be seen through social media where women take the lead - they recruit, distribute and raise funds, without permission or orders from men. They decide and determine their direction and embrace other women under the 'spirit of brotherhood'. All this has given women a sense of authority and independence, at the same time, a sense of worthiness and ownership.

This observation is also consistent with some of Eric Mietz's observations about the recruitment of women into ISIS in the Western Balkans. He found that there were several pull factors for the migration of women to the Islamic State, to create a new state, the romanticism of marrying jihadists, belonging to brotherhood, jihadi subcultures "cool", taking revenge against "infidels", practicing "pure" Islam freely and that is the "religious obligation" to migrate to an Islamic State.

\subsection{Malaysia}

The involvement of women in ISIS in this country was seen in 2013 when reported in the mass media. Malaysian women who travel to the Middle East are apparently intended to marry jihadists. Some Malaysian women in their 30s and 40s join ISIS, and newspaper reports show several Malaysian women arrested while trying to go to the ISIS Caliphate. Most women are arrested and detained before they leave the country except for two, namely Dr. Shams, ISIS star, and Shamimi whose whereabouts are unknown ${ }^{3}$.

Malaysian police said a number of Malaysian women joined the Islamic State of Iraq and Syria (ISIS) to satisfy sexual needs and at least 3 women headed to Daulah Islamiyah, the caliphate founded by IS extremists. One of them is in their 30s, the others $40 \mathrm{~s}$.

Police Inspector General Tan Sri Khalid Abu Bakar said it received information on the Internet. A number of Malaysian women were believed to have joined the ISIS forces and provided 'Jihad Al-Nikah' for militants. Al-Nihad Jihad was a concept in which a woman surrendered to fulfill the sexual needs of fighters who are trying to establish an Islamic state. The goal is to get their morale up. The concept of sexual jihad previously arose in conflict areas such as Syria and Egypt when the country was rocked by conflict.

Not only from Malaysia, women from the UK and Australia are also reported to be heading to Iraq and Syria for the same reason. They are believed to offer to satisfy the militant orgasm of ISIS.

Some women in Malaysia involved in ISIS do not have family members involved in terrorist or Islamic militant activities. However, they have become radical, in many ways

\footnotetext{
${ }^{3}$ Al-Arabiya News, 2014.
} 
including socialization with friends and teachers. They also believe that they can purify their previous sinful lives by choosing a radicalized life.

For example, in October 2014, Ummi Khalsom Bahok, a 25-year-old assistant Credit Manager, was arrested at KL International Airport. She plans to go to Turkey through Brunei to marry ISIS member Aqif Husin Rahaiza. She claimed that being a wife for a jihad was an extraordinary blessing that a wife can get ${ }^{4}$.

One of the figures who emerged as a supporter of ISIS from Malasyia was Dr. Shams. She seems to attract the attention of international media because of her position in various social media channels such as Facebook, Tumblr and Telegram, and also because of her profession, a medical doctor. Dr Shams is a medical doctor who migrated to Syria without the knowledge of her parents. She was still single when she arrived in Syria, but after that, she married a Morrocan jihadist, named Abu Barra.

It was clearly stated earlier that there was a lack of approaches or actions regarding women who were radicalized or became terrorists. So far, these steps are gender blind. This has been confirmed by several key people dealing with terrorism especially in counterterrorism that there is a need to include the perspective of women or women, so that radicalization of women can be tapped. More important when looking at the Malaysian scenario where women are radicalized with the idea of being the wife of jihadists and to cleanse big sins. They chose these radical ways by joining ISIS to win blessings from God Almighty, Allah SWT.

Thus, it can be seen that Malaysian women who are involved in ISIS migrate or try to migrate to Syria to become jihadist wives. Initially, they were less militant compared to their counterparts from Indonesia and the Philippines. However, recent attempts to attack the polls during GE14 recently have raised serious concerns from Malaysian authorities. Most Malaysian women are radicalized through friends, at school or college, and social media. Although some Indonesian women are radicalized through the same channels as Malaysian women, it can be said that many of them are radicalized because their family members are involved in ISIS or groups affiliated with ISIS.

\subsection{Philippines}

In the Philippines, there is evidence that women are active in recruiting and caring for wounded fighters involved in ISIS. Farhana Maute, mother of Maute's brother, is active in recruiting and caring for the injured. There are several women involved as medical staff, funders and sympathizers.

As for Singapore, a woman was arrested for posting and sharing pro-ISIS material online. She had planned to travel to Syria with his young child before being arrested in 2016 .

Philippine security forces also arrested Karen Aizha Hamidon, the wife of a former leader of a small extremist group in Mindanao, who often recruits militants to join the ISIS affiliated group in Marawi. Philippine Justice Minister Vitiliano Aguirre said that Karen was arrested by special agents at her home in Manila in last week on charges of inciting a rebellion.

Hamidon was accused of frequently using social media and instant messages to invite foreigners to join the ISIS-affiliated rebel alliance in the Philippines to gain control of Marawi.

The Manila special agent found around 296 conversations in Telegram and Whatsapp on Hamidon's cellphone, inviting all Muslims in the Philippines, India and Singapore to come

\footnotetext{
${ }^{4}$ Berita Harian Online, October 9, 2014.
} 
to Marawi to establish an ISIS state. The authorities also found around 250 names, most of them suspected foreigners, in Hamidon's cellphone contact. Hundreds of these names are suspected as ISIS sympathizers. Wearing a black burqa, Hamidon was paraded before the media crew during a press conference by the authorities on Thursday (19/10) although he was not allowed to speak.

Hamidon's laptops, cellphones, and a number of other electronic gadgets have also been shown by the investigator as evidence that can help forensic investigations. Hamidon, who is known to be a convert, is married to Mohammad Jaafar Maguid alias Tokboy, a former leader of Ansar al-Khalifa who was killed in a shootout with police in January.

Hamidon and her ex-husband were involved with extremist groups in Singapore and Australia. Aguirre also considers the arrest of Hamidon as the result of government efforts in suppressing terrorism in the Philippines.

Because women are equally exposed and vulnerable to ISIS propaganda and participating in jihad, something must be done to improve it. This should be the main concern of all governments from now on, ISIS in particular, and leaders of pro-ISIS militant groups in the region, have called on women to be the frontline in jihad, especially at the Caliphate posts in the region. . This call is a powerful motivating factor for women who are radicalized to engage in acts of violence including suicide bombings. With advances in technology, it provides an interactive, fast and safe international platform that can be used for radicalization and recruitment. This will make women more vulnerable than before. Although ISIS stipulates that the main role of women is at home and needs to ask permission if they want to leave home, women actually enjoy cyberspace through social media and online

\subsection{Indonesian Experience}

Today, in Indonesia the role of women in radicalism cannot be underestimated. Although the number of women involved in terrorist cases is still relatively small, this trend continues to increase. In the past, the scope of women's involvement in extremist groups was strongly influenced by the work patterns of organizations. During the heyday of Jemaah Islamiyah - the organizations that masterminded the Bali and I bombings (2002 and 2005) and the Australian embassy bomb (2004) - the role of women was still limited. Women were not sent to the front lines, were not included in military training, let alone assigned to carry out operations. The main task of women [at JI] is looking after children, cooking, and preaching to fellow women.

But the truth is that for a long time women in extremist circles already had a strong desire to be involved in what was believed to be a struggle against tyranny and renunciation of God. For the most part, this is thanks to their activities as active participants in the Koranic recitation groups. They become 'translators' directly from the concept of jihad in theory and are converted into practice.

To advance to the battlefield, generally women are deemed inappropriate. Their role is more often as a driver and strengthened faith of husbands who want to go 'jihad'. (Lies Marcoes, Why do women join radical groups, https://rumahkitab.com/women-join-radicalgroups/accessed December 12, 2019)

However, Amy Chew (South China Morning Post, May 5, 2019) reports that there is a new phenomenon which is deadly to women who are radicalized by ISIS ideology who become suicide bombers and their children in jihad efforts. Here, experts see, increasing radicalization of women in married couples, due to the influence of their husbands, tends to endanger the whole family. According to Nasir Abbas, a former leader of Jemaah Islamiah (JI) linked to al-Qaeda and used to be a jihadist sought in Southeast Asia: for these women, 
maternal instincts to protect their children were replaced by a search for "fast walking" to heaven.

CSIS Jakarta Research (Intolerance and Radicalism in Women, 2017) also mentioned that one of the reasons for the increasing involvement of women in acts of terror, in tune and in line with changes in the ISIS strategy since 2013.

In Indonesia, pro-ISIS circles often spread their propaganda that Nusaibah bint Ka'ab Ansyariyah, a female Muslim hero, nicknamed Ummu Umarah, who fought alongside the Prophet in the Uhud war and with Khalid bin Walid in the Yamamah war, was a figure who motivated women to appear in the Ummah the vanguard in this "struggle". ISIS propaganda emphasizes, these Muslim women fighters have given examples of women who are also capable and have the same responsibility in defending Islam. Social media (social media) plays an extraordinarily effective role in changing women's views. With interesting narratives and propaganda, many women are attracted, captivated, by the radical narratives loaded by this media and decide to follow and take roles according to their capacity and potential.

Since ISIS was pushed and collapsed in Syria and Iraq, ISIS has changed the tactics of the struggle by calling for amaliyah activities (acts and terror attacks) to be carried out in any way and anywhere in the world. This change provides open space for women to play roles ranging from disseminating information in cyberspace to executing on the ground.

The inclusion of ISIS's role and influence in Indonesia through its cells, networks and supporters among Muslim youth, ulama, religious teachers and existing hardliners, has led to a shift in the role of women in the extreme violence movement in Indonesia. At the beginning of the terrorist movement where Jemaah Islamiyah (JI) became a pioneer actor of extreme violence in Indonesia, women only played the role of logistic supporter (caring for the interests of men), educators (educators or successors of the spirit of jihad to children, networks and families) and reproductive roles (gave birth to new jihadists) in this movement. But the presence of new players namely the Islamic Countries of Iraq and Syria (ISIS) in Indonesia which provides wider space for women's participation, opens new opportunities for women to participate and take roles.

Admittedly, ISIS in its mission, campaign and propaganda highly appreciates the women where ISIS claims that women are not merely sexual objects, but are mothers to the next generation and guardians of ISIS ideology. Although the Caliphate of ISIS was defeated in 2018, ISIS influence and operations continue to be a threat to countries around the world. The Havlicek study (2015: 9-10) shows that there is compelling evidence that ISIS appreciates female members more than men. For example, in the hostage crisis in Jordan in January 2015.

Even women can play a wider role because in a patriarchal culture, women are seen as harmless and less suspicious than men. But Mia Bloom and Chelsea Diamon note that the views and perceptions of the role of capability in terrorism are usually limited to assisting men or obeying men's commands in an act of terror. But it turns out that it is wrong and no longer appropriate because the involvement of women and children is mainly not merely due to obedience and doctrine by the husband. It is actually possible to be exacerbated by access to certain ideologies through cyberspace which justifies the understanding of radicalism among women, mothers. And don't forget, terrorism activities that flow from families where women (mothers) are involved, are very difficult to overcome through an ideological approach.

The Dete Alia Study (2018) revealed that the phenomenon of the widespread role of women in terrorism is very sad, because how a mother who should protect her child from danger invites her child to participate in dangerous activities that not only take away her life 
but also the lives of others. The Surabaya case is again interesting, because the woman who became the bride of a suicide bombing succeeded in realizing her dream of being a bride and "martyrdom". Here, women and children are not only victims but also participate in a radical movement: terrorism. Before the Surabaya suicide bombing, there were acts of terror by two young women in Mako Brimob who were about to carry out an act to stab police using scissors like an attack that occurred in Paris. Clearly, this phenomenon shows that women are now taking an important role in the extreme violence movement. Dian Yulia Novi became a beginner in the movement at Mako Brimob, then Ika Puspitasari and several other women who played different roles.

Women involved in a series of suicide bombings by a family in Surabaya, Indonesia (May 13, 2018), which was carried out simultaneously in three churches in Surabaya, Sunday (5/13). The Surabaya bomb attack was very shocking and shocked the public. What is particularly concerning is that the suicide bombing case involved a woman who, together with her husband, persuaded and brought her children to be involved.

So that the phenomenon of family suicide bombing in Surabaya shifts the landscape of extreme violence that occurred in Indonesia, which was previously dominated by men and the action is usually carried out alone or in groups in action, and does not involve family members let alone children. The case of the church bombing in Surabaya and Surabaya Mapolres changed the conventional pattern of violence because the involvement of women who persuaded minors was irrational and had never been imagined by the public.

So that the phenomenon of family suicide bombing in Surabaya shifts the landscape of extreme violence that occurred in Indonesia, which was previously dominated by men and the action is usually carried out alone or in groups in action, and does not involve family members let alone children. The case of the church bombing in Surabaya and Surabaya Mapolres changed the conventional pattern of violence because the involvement of women who persuaded minors was irrational and had never been imagined by the public.

This phenomenon is very sad, because how a mother who should protect her child from danger would invite her to participate in dangerous activities that not only take away her life but also the lives of others. The Surabaya case is again interesting, because the woman who became the bride of a suicide bombing succeeded in realizing her dream of being a bride and "martyrdom". Here, women and children are not only victims but also participate in a radical movement: terrorism.

This is parallel with the view of the National Commission on Violence Against Women who is concerned about the trend in recruiting women to become bombers. This is because of the assumption that women are potentially more militant than men. Women are also considered adept at manipulating situations so that they are not easily suspected by opponents for security reasons. Komnas Perempuan reminds that going forward, terrorists will continue to utilize the role of women as mothers as well as strategically to transmit radical ideologies, and prepare children to be martyred. Therefore, going forward, society and the state must strive to prevent, be aware of and overcome the role of women in acts of terrorism because it is almost certain, the role of women is increasingly maximized by men in this violent, cruel and brutal act.

Suicide bombings by women are classified as a new phenomenon in Indonesia that is very surprising. In the level of national culture, so far Indonesian women only play the role of a housewife whose function is to guide and care for children while serving the needs of their husbands' lives.

The social status of Indonesian women has experienced a very violent shift since the emergence of the feminism movement in the world. However, this shift in women's social 
status is only focused in the realm of public careers as an effort to break down gender stereotypes.

In contrast to the shift in the social status of women in radical groups that adheres to certain religious sects. In their ideological level, women have the right and obligation to fight and wage jihad as a man does.

The weak power of reasoning (rationality) and the lack of understanding of women's spirituality in these radical groups, make women easily exposed to misleading religious teachings and ideologies. However, they were promised to go to heaven if they died in fighting or fighting.

Chaula Rininta Anindya, an analyst with Ranyangatnam School of International Studies (RSIS) of Nanyang University in Singapore, said female bombers affirmed the fact that the universe of terrorism was no longer dominated by men only.

"Why women? Because strategically and tactically it is clear that women have an effective role. Strategically, the effects of terror are large because (the public) is not accustomed to women as attackers. Usually there will be an overreaction that will be the main goal of his terrorist acts, "5.

What Chaula said might have a point. At present, the role and function of women in radical groups has been increased to carry out the tasks of jihad that are usually carried out by men. These women are obliged to wage jihad in a peaceful country (a state in a state of no war). Acts of female jihad, such as the suicide bombing in the Surabaya church, are even more sadistic than those of male jihadists.

For the future, these terrorists will continue to use women as executors in the field, because in general women's behavior is not too easily suspected by security forces.

In checking bombs by security forces, generally bombs carried by women terrorists often escape detection, due to ethical reasons and politeness when carrying out physical examinations of women.

At present, women who are ready to become 'brides' to carry out suicide bombings, are suspected of increasing numbers (former widows of ISIS terrorists). Women have important potential for terrorists to be used as suicide bomb executors.

This is because terrorist groups' networks see that women can be more militant and manipulate security forces.

"And take advantage of the role of women as strategic mothers to transmit radical ideologies and prepare children to be martyred,"6.

National Commission on Violence Against Women explained, the results of Global Study 1325 stated that gender-based violence became a tactic of the terrorist movement. You see further the root of the problem behind the involvement of women in terrorism. Women are often the perpetrators, as targets of recruitment to accept radical doctrine and become ideological tools, to be martyred by committing violence.

\section{Conclusion}

In the Southeast Asian context, reports have shown that women from Indonesia, the Philippines, Singapore and Malaysia have been involved in ISIS at various levels. Of the four countries, reports indicate that women in the region have participated in ISIS as suicide bombers, recruiters and propagandists, sympathizers and funders.

\footnotetext{
${ }^{5}$ Chaula said when talking to konfrontasi.com, one of the media in Jakarta on Tuesday, May 15, 2018

${ }^{6}$ The statement of the National Commission for Women received on Wednesday (5/16/2018) night.
} 
It can be observed that, of all countries in Southeast Asia, four countries are reported to have women involved in ISIS, namely Indonesia, Malaysia, the Philippines, and Singapore. Of all, women in Indonesia appear to be the most active and radical, followed by the Philippines, Malaysia, and finally Singapore.

In Indonesia, a series of suicide bombings that occurred in Surabaya and Sidoarjo, East Java, recently caught the attention of many parties. One of them is because the culprit is a family consisting of father, mother, and children.

Terrorism observer from the University of Indonesia (UI), Solahudin, sees that there are several reasons underlying the involvement of women and children in several suicide bombings in East Java some time ago. First is security reasons. "If it is done by women and children it is more difficult to be identified, not too suspicious, let alone a family."

Another reason is to get a wider range of coverage, even to the whole world. Solahudin said, suicide bombings carried out by adult men would have been common. However, it would be a different story if the suicide bombing was carried out by women and involving children. This will be a concern, especially for foreign media. If the perpetrators of the mother and child are extraordinary, they will provide broad coverage. That is why foreign media are covering the news because they have high news values.

The final reason is that suicide bombers give messages delivered to their own networks. The message in question is related to the courage to carry out suicide bombings. The message is, just children are brave, women are brave, cook you (adult men) do not dare? In the face of the rise of terrorism by Muslim men and women, there must be a message of caution in fighting terrorism.

So far, the success of counter-narratives aimed at civil society is highly dependent on three factors namely, the messenger, the message and the message platform that is distributed. These factors need to be brought together to convey the right message to the right audience. Therefore, women are needed in this counter-narrative to connect their experiences with other female audiences. This means that the substance of counter-narratives must also be related to Islamic principles and teachings including the actions of the Prophet Muhammad and his companions. This will be useful as ways, background and tactics against terrorism, radicalism and even hidden ISIS transactions and actions.

\section{References}

Anne Speckhard and Khapta Akhmedova, "Black Widows: The Chechen Female Suicide Terrorists," in Female Suicide Bombers: Dying for Equality? ed. Yoram Schweitzer (Tel Aviv: Jaffee Center for Strategic Studies, 2006), 63-80.

Amy Chew, South China Morning Post, May 5, 2019

BBC News, "Lake Chad's Baga Sola Town Hit by Suicide Bombers," Oct. 10, 2015. www.bbc.com/news/world-africa-34498417.

Christine Eifler and Ruth Seifert, Gender Dynamics and Post-Conflict Reconstruction,Frankfurt am Main, Berlin, Bern, Bruxelles, New York, Oxford, Wien, 2009. $298 \mathrm{pp}$

CSIS Jakarta, Intoleransi Dan Radikalisme di Kalangan Perempuan, Report, 2017

Daily Mail (London), "Iraqi Woman Recruited Army of Female Suicide Bombers by Having Them Raped... Then Told Them Martyrdom Was Only Way to Escape Shame," Feb. 5, 2009, www.dailymail.co.uk/news/article-1134976/Iraqi-woman-recruited-army-femalesuicide-bombers-having-raped - told-martyrdom-way-escape-shame.html.

David C. Rappaport. Current History 100, no. 650 (December 2001): 419-25. 
Lindsey A. O'Rourke, What's Special about Female Suicide Terrorism? Journal Security Studies Volume 18, 2009 - Issue 4, pp. 681-718

Margaret Thatcher, speech to American Bar Association, July 25, 1985, www.margaretthatcher.org/document/106096.

Robert Pape, interview by Lynn Neary, NPR, May 21, 2009, www.npr.org/templates/story/story.php?storyId=104391493.

James Adewunmi Falode, "The Nature of Nigeria's Boko Haram War, 2010-2015: A Strategic Analysis," Perspectives on Terrorism 10, no. 1 (2016): 41-52.

UNICEF, Beyond Chibok: Over 1.3 Million Children Uprooted by Boko Haram Violence, April 2016. www.unicef.org/infobycountry/files/Beyond_Chibok.pdf.

Dounia Bouzar, "Rescue Mission: Freeing Young Recruits from the Grip of ISIS," Scientific American Mind 27, no. 3 (May 2016): 41-43.

Institute for Economics and Peace, Global Terrorism Index 2015: Measuring the Impact of Terrorism, 2-7, 26-28 www.visionofhumanity.org/sites/default/files/2015\%20Global\%20Terrorism\%20Index \%20Report_1.pdf.

Lies Marcoes, Why do women join radical group, https://rumahkitab.com/women-joinradical-groups/accessed December 12,2019)

Lindsey A. O'Rourke, What's Special about Female Suicide Terrorism? Journal Security Studies Volume 18, 2009 - Issue 4, pp. 681-718

Christine Eifler and Ruth Seifert, Gender Dynamics and Post-Conflict Reconstruction,Frankfurt am Main, Berlin, Bern, Bruxelles, New York, Oxford, Wien, 2009. $298 \mathrm{pp}$

Institute for Conflict Policy Analysis [IPAC], Report 2017Mothers to Bombers: The Evolution of Indonesian Women Extremists. IPAC Report No. 35.Retrieved from http://file.understandingconflict.org/file/2017/01/IPAC_Report_35.pdf

Sarah Havlicek, The Islamic State's War on Women and Girls. Institute for Strategic Dialogue. Institute for Policy Analysis of Conflict (IPAC), IPAC Report No. 33, 1-18, 2015

Al-Arabiya News, 2014

Berita Harian Online, October 9, 2014. 